\title{
THE ROLE OF ISLAMIC RELIGIOUS EDUCATION TEACHERS IN INSTRUCTING RELIGIOUS VALUE
}

\author{
Ahmad Hariandi, Brigita Novianti Butarbutar, Endang Juliana, Puput \\ Wulandari, Tati Karyati \\ Universitas Jambi, Jambi, Indonesia \\ Email: brigitabutarbutar@gmail.com
}

DOI: 10.35445/alishlah.v12.i2.166

Accepted: December $12^{\text {th }}, 2019$. Approved: August $4^{\text {th }}, 2020$

Published: December $30^{\text {th }}, 2020$

\begin{abstract}
This research aims to identify the role of Islamic religion teachers in instilling religious values in elementary schools. Data collecting is done by making direct observations of intensive learning activities and learning outside which are considered to prioritize attitude or religious. The research method used is a qualitative descriptive approach. This type of research is a phenomenological research. This research examines a phenomenon that exists in SD Negeri 182/1 Lindung Hutan. The result of this research shows that the role of Islamic religious education teachers is very important in instilling religious values in schools. The teacher is a model in the process of instilling religious value for the students.
\end{abstract}

Keywords : The role of Islamic Religion Teacher, Religius value

\section{PERAN GURU PENDIDIKAN AGAMA ISLAM DALAM MENANAMKAN NILAI RELIGIUS}

\begin{abstract}
Abstrak
Penelitian ini bertujuan untuk mengidentifikasi peran guru agama islam dalam menanamkan nilai religius di sekolah dasar. Pengumpulan data dilakukan dengan melakukan observasi secara langsung terhadap kegiatan intensif pembelajaran hingga pada kegiatan diluar jam pembelajaran. Penilaian masih mengedepankan sikap atau nilai religius. Metode penelitian yang digunakan adalah pendekatan deskriptif kualitatif. Jenis penelitian ini merupakan penelitian fenomenologi dikarenakan penelitian ini meneliti suatu fenomena yang ada di SD Negeri 182/I Hutan Lindung yang dilakukan secara mendalam. Sumber data utama dalam penelitian ini didapat dari pengamatan berupa observasi dan teknik yang
\end{abstract}


Al-Ishlah: Jurnal Pendidikan - ISSN: 2087-949o (p); 2597-940X (e)

Vol. 12, No. 2 (2020)

digunakan dalam penelitian ini adalah teknik snowball sampling. Hasil penelitian menunjukkan bahwa peran guru Pendidikan Agama Islam sangat besar dalam menanamkan nilai religius di sekolah. Guru merupakan teladan bagi siswanya dalam penanaman nilai-nilai keagamaan.

Kata Kunci : Peran Guru Agama Islam, Nilai Religius

\section{PENDAHULUAN}

Pendidikan agama sejatinya merupakan suatu hal yang sangat dibutuhkan pada saat ini. Hal tersebut dikarenakan telah tampak kemerosotan terutama pada nilai moral, akhlak dan karakter manusia. Untuk menghindari hal tersebut tentunya upaya dalam peningkatan kualitas pendidikan sangat diperlukan khususnya pada sisi religius. Upaya tersebut dapat dilakukan dengan pendidikan di sekolah. Sesuai dengan rumusan pasal 3 UU No. 20 Tahun 2003 tentang sistem pendidikan nasional berfungsi mengembangkan kemampuan dan membentuk karakter serta peradaban bangsa yang bermartabat dalam rangka mencerdaskan kehidupan bangsa. Pendidikan diharapkan dapat membentuk siswa yang berkarakter religius.

Menurut Sjarkawi (2008:29) nilai religius merupakan nilai yang ada pada setiap individu yang bersifat ketuhanan dengan kata lain sebuah nilai yang melambangkan kepatuhan kepada tuhan untuk menjalankan perintah agama. Nilai ini sangat dibutuhkan peserta didik pada zaman ini. Nilai ini harus sudah ditanamkan sejak dini. Pada jenjang pendidikan sekolah dasar peran guru dalam penanaman nilai religius dapat dikatakan sangat penting. Peran guru Pendidikan Agama Islam sebagai pengarah potensi dan kepribadian peserta didik dalam pendidikan islam yang meliputi nilai iman, ibadah dan akhlak dari peserta didik. Seorang guru agama islam bukan hanya dapat menjalankan pembelajaran agama islam tetapi juga melakukan upaya agar tujuan dari adanya pendidikan agama islam tercapai. sisi religius merupakan fokus awal dalam tujuan pendidikan agama islam termasuk penerapannya di sekolah dasar.

Menurut Lampiran Peraturan Menteri Pendidikan Nasional Nomor 16 Tahun 2007 Tanggal 4 Mei 2007, kompetensi guru Pendidikan Agama Islam meliputi dua hal. Pertama, menginterpretasikan materi, struktur, konsep, dan pola pikir ilmu-ilmu yang relevan dengan pembelajaran Pendidikan Agama Islam (PAI). Kedua, menganalisis materi, struktur, konsep, dan pola pikir ilmu-ilmu yang relevan dengan pembelajaran. Dalam hal ini penguasaan PAI secara umum meliputi aqidah, akhlak, sejarah kebudayaan islam dan fiqh. Selain itu juga harus menguasai aspek-aspek yang lebih detail seperti ushul fiqh, kalam, tasawuf, metodologi studi Islam, tafsir, bahasa Arab dan lain-lain. Kompetensi yang tidak kalah penting adalah memberikan teladan dan meningkatkan kualitas dan 
Vol. 12, No. 2 (2020)

profesionalitasnya yang mengacu pada masa depan tanpa melupakan peningkatan kesejahteraan kepada peserta didik dan lingkungannya.

Guru PAI mempunyai peranan yang lebih di berbagai lingkungan baik keluarga, masyarakat maupun sekolah. karena guru PAI dianggap orang yang mempunyai pengetahuan agama lebih dibandingkan dengan orang lain. Sehingga peranannya haruslah mencerminkan nilai-nilai ajaran Islam yang diemban dan diajarkannya. Menurut Damsar (2011), guru tidak lepas dari 2 fungsi yaitu fungsi laten dan fungsi manifest. Fungsi laten adalah fungsi yang diharapkan, disengaja dan disadari guru oleh masyarakat pada suatu ruang. Fungsi ini terdiri dari: guru sebagai pengajar, pendidik, teladan dan sebagai motivator. Fungsi manifest adalah fungsi yang tidak diharapkan, disengaja dan disadari guru terhadap masyarakat, antara lain: guru sebagai pelabel, penyambung lidah kelas menengah atas, pengekal status quo.

Peran guru PAI menurut Novan A.W (2015) adalah sebagai pengajar yang bertugas membina perkembangan pengetahuan, sikap atau tingkah laku, dan keterampilan. Selain itu, guru PAI juga sebagai pembimbing atau pemberi bimbingan yang meliputi bimbingan belajar dan bimbingan perkembangan sikap atau tingkah laku. Guru PAI juga sebagai pemimpin atau manajer kelas yang juga sebagai administrasi, yaitu pengelola kelas atau pengelola interaksi belajar mengajar. Terdapat dua aspek dari masalah pengelolaan yang perlu mendapat perhatian oleh guru PAI, yaitu membantu perkembangan anak didik sebagai individu dan kelompok serta memelihara 36 kondisi belajar yang sebaik-baiknya di dalam ataupun di luar kelas.

Peran guru dalam metode pembelajaran PAI menurut Syahraini Tambak (2014) yaitu sebagai pendorong kesadaran keimanan, sebagai pendorong penggunaan akal pikiran peserta didik, sebagai motivator pembelajaran dengan menerapkan prinsip-prinsip psikologis dan pedagogis sebagai kegiatan antar hubungan pendidikan yang terealisasi melalui penyampaian keterangan dan pengetahuan agar peserta didik mengetahui, memahami, menghayati, dan meyakini materi yang diberikan, serta meningkatkan keterampilan olah pikir. Guru juga sebagai sumber belajar dan fasilitator. Peran guru sebagai fasilitator yaitu guru mewujudkan dirinya sebagai pengembang, penggugah, dan pendorong bagi kesuksesan peserta didik dalam pembelajaran. Dan terakhir, guru PAI sebagai pengelola dimana guru dapat mengelola peserta didik dengan baik dan sukses dalam pembelajarannya.

Berdasarkan hasil observasi peneliti di SD Negeri 182/I Hutan Lindung Muara Bulian, terlihat adanya peranan Guru pendidikan agama islam di sekolah tersebut. Hal ini tergambar pada kegiatan intensif pembelajaran hingga pada kegiatan di luar jam pembelajaran yang dinilai masih mengedepankan sikap atau nilai religius. Oleh karena itu, berdasarkan uraian yang telah dikemukakan diatas, 
Vol. 12, No. 2 (2020)

peneliti ingin menganalisis lebih jauh tentang peran guru PAI dalam menanamkan nilai religius di SD Negeri 182/I Hutan Lindung Muara Bulian. Berdasarkan konteks dari penelitian, maka rumusan masalah yang akan dikemukakan oleh peneliti adalah bagaimana analisis peran guru agama islam dalam menanamkan nilai religius di SD Negeri 182/I Hutan Lindung Muara Bulian.

\section{METODE PENELITIAN}

Metode penelitian yang digunakan adalah pendekatan deskriptif kualitatif. Jenis penelitian ini merupakan penelitian fenomenalogi dikarenakan penelitian ini meneliti suatu fenomena yang ada di SD Negeri 182/I Hutan Lindung yang dilakukan secara mendalam. Penelitian fenomenologi mencoba menjelaskan atau mengungkap makna konsep atau fenomena pengalaman yang didasari oleh kesadaran yang terjadi pada beberapa individu. Menurut Creswell (1998:54), pendekatan fenomenologi menunda semua penilaian tentang sikap yang alami sampai ditemukan dasar tertentu.

Penelitian ini dilakukan di SD Negeri 182/I Hutan Lindung, Kabupaten Batang Hari, yang dilaksanakan selama semester ganjil 2019/2020. Data merupakan subjek yang akan diteliti untuk memperoleh informasi yang dibutuhkan dan akan menghasilkan data deskriptif kualitatif tentang analisis peran guru PAI dalam menanamkan nilai religius di SD Negeri 182/I Hutan Lindung.

Sumber data utama dalam penelitian ini didapat dari pengamatan berupa observasi. Objek yang diobservasi adalah moral dan karakter peserta didik, prilaku peserta didik serta kegiatan pembelajaran yang dilakukan oleh guru PAI di SD Negeri 182/I Hutan Lindung. Data skunder dapat diperoleh melalui foto, dokumen dan sumber buku yang berkaitan dengan penelitian ini.

Teknik yang digunakan dalam penelitian ini adalah teknik snowball sampling. Snowball sampling adalah teknik pengambilan sampel dengan bantuan key-informan dan dari key-informan inilah akan berkembang sesuai petunjuknya. Dalam hal ini peneliti hanya mengungkapkan kriteria sebagai persyaratan untuk dijadikan sampel (Subagyo, 2006:13). Snowball samping juga merupakan teknik penentuan sampel yang mula-mula jumlahnya kecil, kemudian membesar.

Dalam teknik pengumpulan data dilakukan dengan observasi. Observasi disebut juga pengamatan, yang meliputi kegiatan pemantauan perhatian terhadap suatu objek dengan menggunakan seluruh indera. Observasi sebagai metode pengumpulan data banyak untuk mengamati tingkah laku individu atau proses terjadinya kegiatan yang dapat diamati. Observasi yang diambil dalam penelitian ini adalah observasi berperan serta dan observasi terstruktur. Dalam observasi berperan serta, peneliti melakukan observasi pada saat kegiatan yang diamati sedang berlangsung. Observasi terstruktur dilakukan oleh peneliti karena peneliti sudah tahu gambaran kegiatan yang akan diamati. 
Vol. 12, No. 2 (2020)

Dalam penelitian ini menggunakan wawancara terstruktur sebagai teknik pengumpulan data. Wawancara terstruktur adalah wawancara yang bebas dimana peneliti menggunakan pedoman wawancara yang telah tersusun secara sistematis dan lengkap untuk pengumpulan datanya. Pedoman wawancara yang akan digunakan berupa garis-garis besar permasalahan yang akan ditanyakan (Arsil, 2019). Wawancara yang akan dilakukan terhadap guru PAI di SD negeri 182/I Hutan Lindung. Topik yang akan dijadikan bahan wawancara adalah analisis peran guru agama islam dalam menanamkan nilai religius di SD Negeri 182/I Hutan Lindung Muara Bulian.

Penelitian ini menggunakan cara triangulasi metode dimana peneliti bertindak sebagai pengumpulan data dari sumber data sekaligus menguji kredibilitas data. Triangulasi dalam pengujian kredibilitas diartikan sebagai pengecekan sumber, berbagai cara dan berbagai waktu. (Sugiyono, 2014: 327). Pada penelitian ini menggunakan model Miles and Huberman (1984), di mana analisis data kualitatif dilakukan secara interaktif yang dilakukan terus menerus sampai tuntas hingga datanya sudah jenuh. Dalam analisis data terdapat tiga langkah atau tahapan, yaitu:

a. Reduksi Data, dalam penelitian ini reduksi yang dilakukan peneliti seperti: Mengobservasi ruang kelas yang mengadakan kegiatan literasi. Dengan reduksi, peneliti dapat mengumpulkan data selanjutnya, memberikan gambaran yang jelas mengenai hal yang diteliti.

b. Display Data (penyajian data), data hasil reduksi kemudian disajikan dan dibandingkan dengan kajian teori. Dengan men-display data dalam bentuk uraian akan memudahkan peneliti untuk memahami apa yang terjadi, merencanakan kerja selanjutnya berdasarkan apa yang telah dipahami.

c. Verifikasi data, langkah ketiga setelah penyajian data ialah pengambilan kesimpulan dan verifikasi. Pada penelitian kualitatif, kesimpulan awal yang diambil masih bersifat sementara, sehingga dapat berubah setiap saat apa bila tidak didukung bukti-bukti yang kuat. Dari penelitian ini mengetahui peran orang tua dalam mendukung gerakan literasi sekolah.

Prosedur yang digunakan dalam penelitian ini meliputi:

a. Tahap Persiapan, peneliti mempersiapkan instrumen penelitian, dan meminta izin kepada informan atas kesiapannya untuk menjadi responden dalam penelitian.

b. Tahap Pelaksanaan Penelitian, peneliti mengumpulkan data dengan instrument yang telah disiapkan, kemudian menganalisa data dan menyimpulkan data yang diperoleh.

c. Tahap Penyelesaian, peneliti menulis hasil dalam bentuk laporan penelitian. 
Al-Ishlah: Jurnal Pendidikan - ISSN: 2087-949o (p); 2597-940X (e)

Vol. 12, No. 2 (2020)

\section{HASIL DAN PEMBAHASAN}

Berdasarkan hasil observasi secara langsung yang telah dilakukan peneliti tentang peran guru PAI dalam menanamkan nilai religius di SD Negeri 182/I Hutan Lindung, diketahui bahwa sebelum pelaksanaan kegiatan pembelajaran, pertama kali, guru PAI membariskan siswa di depan kelas lalu memberikan senyum dan sapa kepada guru. Kemudian juga guru PAI membiasakan siswa untuk mengucapkan salam terlebih dahulu sebelum masuk ke kelas.

Sesampainya di ruang kelas, guru mengajak siswa untuk berdoa sebelum memulai pelajaran. Setelah itu dilanjutkan membaca Alquran surat pendek. Selesai siswa berdoa dan membacakan surat pendek, guru juga tidak lupa mengawalinya dengan rasa syukur kepada Tuhan atas rahmatNya yang telah diberikan sehingga dapat melaksanakan pembelajaran dengan baik.

Ketika peneliti melakukan observasi di kelas, tema yang diajarkan guru adalah mengenai rasa toleransi terhadap sesama umat beragama. Siswa yang berada di ruang kelas itu juga tidak semuanya beragama Muslim. Guru mengajarkan kepada siswa agar sebagai warga negara yang memiliki keanekargaman termasuk agama harus saling menghargai dan mengasihi. Guru mengajak siswa untuk menghargai sesama temannya yang memiliki keyakinan berbeda. Siswa juga harus menghormati cara beribadah temannya serta ketika waktunya mereka beribadah. Tidak lupa juga guru mengingatkan kepada siswa sebagai umat yang beragama, siswa tidak boleh meninggalkan sholatnya atau ibadahnya. Karena ibadah merupakan salah satu wujud syukur kita kepada Tuhan.

Kemudian pada bagian akhir proses pembelajaran, guru menutupnya dengan memberikan permainan. Permainannya adalah berikan salam senyum dan sapa sebanyak mungkin kepada temannya. Akhirnya ada siswa yang sedang bertengkar dengan siswa lainpun berhubungan baik kembali dan merasakn kedamaian. Setelah itu, guru menutup pembelajaran bersama dan bersalam dengan gurunya sebelum keluar kelas.

Berdasarkan hasil wawancara pada tanggal 06 Agustus 2019 pada guru PAI di SD Negeri 182/I Hutan Lindung mengenai peran guru PAI dalam menanamkan nilai religius di SD Negeri 182/I Hutan Lindung diketahui bahwa terdapat berbagai macam karakter siswa di SD Negeri 182/I Hutan Lindung ini. Sampai sejauh ini, siswa yang menuntut ilmu di sekolah ini memiliki karakter yang baik. Hal ini dikarenakan sekolah memberlakukan sistem hukuman bagi anak yang melanggar aturan. Sekolah ini juga jauh dari keramaian sehingga kondusif dalam melaksanakan proses belajar mengajar.

Selain itu, agama, ras dan suku siswa yang bersekolah di sini juga beragam. Mengenai agama yang dianut oleh siswa di sekolah ini bukan hanya terdiri dari muslim saja melainkan ada juga siswa yang menganut agama kristen. Namun, mayoritasnya siswa yang bersekolah di sini adalah muslim. Menurut guru 
Vol. 12, No. 2 (2020)

PAI yang diwawancarai, dia punya cara tersendiri dalam menanamkan nilai religius kepada peserta didiknya dan salah satunya adalah dengan menerapkan program 5S (Senyum, Salam, Sapa, dan Sopan Santun). Dengan program 5S ini, nilai akhlak dan ibadahnya telah dilakukan. Kemudian juga guru melakukan acara yasinan yang dilakukan setiap hari jumat untuk mengembangkan nilai keagamaannya. Penerapan program $5 \mathrm{~S}$ juga bukan hanya tugas guru PAI melainkan untuk semua warga sekolah.

Selain itu, ada beberapa kegiatan yang yang mendukung dan mengandung penanaman nilai religius kepada peserta didik di sekolah ini, diantaranya adalah memberi salam kepada guru sebelum masuk ke kelas, berdoa sebelum dan sesudah belajar, acara yasinan yang rutin dilakukan setiap hari jumat, dan merayakan hari-hari besar keagamaan seperti mengadakan acara maulid nabi, isra miraj dan hari besar keagamaan lainnya.

Dalam upaya penanaman nilai-nilai keagamaan ini juga mengalami kendala. Salah satu kendala dari peserta didik yaitu kebiasaan buruk di rumah yang dibawa oleh peserta didiknya ke sekolah. Contohnya seperti kebiasaan berbicara kotor dari rumah yang kemudian dibawa ke sekolah sehingga mempengaruhi teman-temannya yang lain dan bisa juga teman-teman dari si anak tersebut meniru apa yang dilakukan oleh si anak. Hal tersebut menjadi tantangan tersendiri bagi guru karena guru harus mengubah kebiasaan buruk tersebut. Karena itu, jika peserta didik berasal dari lingkungan rumah yang kurang disiplin, maka hal tersebut akan sulit diubah dan membutuhkan sebuah proses dan cara yang tepat bagi guru untuk mengatasinya.

Salah satu solusi yang dapat berikan atas permasalahan tersebut adalah dengan menanamkan nilai agama terlebih dahulu. Karena ketika siswa mengerti dan memahami agamanya dengan baik, maka siswa akan terbiasa menghilangkan kebiasaan buruk tersebut. Nilai agama merupakan hal penting dalam kehidupan manusia. Selain itu, jangan pernah mengeluh dan tetap berusaha dalam menanamkan nilai agama yang baik kepada peserta didik.

\section{1) Data Reduksi}

Berdasarkan hasil penelitian melalui observasi dan wawancara tentang peran guru PAI dalam menanamkan nilai religius di SD Negeri 182/I Hutan Lindung. Peran guru PAI sangat berperan penting dalam menanamkan nilai religius di sekolah. Dengan segala tindakan maupun pembelajaran yang dilakukan guru PAI dapat membuat suasana sekolah tentram, damai, saling menghargai sesama, serta tidak lupa bersyukur kepada Tuhannya.

\section{2) Data Display}

Peran guru PAI ternyata sangat beragam dalam menanamkan nilai religius di SD Negeri 182/I Hutan Lindung. Hal ini dimulai dari hal kecil terlebih dahulu 
Vol. 12, No. 2 (2020)

agar siswa mudah memahami makna nilai religius serta manfaatnya dalam kehidupan. Guru PAI juga perlu melakukan hubungan yang baik dengan orang tua karena orang tua jugalah yang perlu menanamkan nilai religius.

\section{3) Verifikasi Data}

Berdasarkan hasil observasi dan wawancara tentang peran guru PAI dalam menanamkan nilai religius di SD Negeri 182/I Hutan Lindung, peran guru PAI sangat banyak kontribusinya dalam menanamkan serta menerapkan nilai religius kepada siswa. Bentuk nilai religius yang dilakukan oleh guru PAI adalah dengan melakukan salam sebelum masuk kelas, berdoa sebelum dan sesudah belajar, mengajak siswa untuk selalu bersyukur, membiasakan siswa masuk dan keluar untuk memberikan salam, mengajak siswa menghargai sesamanya, meningatkan untuk selalu sholat atau beribadah serta adanya kegiatan yasinan setiap hari jumat.

Dari hasil observasi, wawancara dan dokumentasi yang telah peneliti lakukan dapat ditemukan penelitian sebagai berikut :

1. Guru PAI sangat berperan penting dalam menanamkan nilai religius kepada siswa di SD Negeri 182/I Hutan Lindung. Hal ini dilihat dari semua bentuk yang dilakukan seperti memberi salam, berdoa, menerapkan program 5S hingga acara religius yang dilakukan yaitu yasinan.

2. Dengan adanya guru PAI di sekolah, siswa semakin menyadari bahwa agama dan akhlak yang baik itu penting. Hal ini terbukti karena siswa jarang sekali bertengkar dengan temannya.

3. Guru PAI selalu mencari solusi dari berbagai kesulitan yang ditemui dalam menanamkan nilai religius di sekolah.

4. Guru PAI dan orang tua bersama-sama dalam menanamkan nilai religius kepada siswa. Hal ini terlihat dengan cara ketika adanya masalah yang terjadi di sekolah, guru PAI juga memecahkan masalah bersama-sama dengan orang tua.

5. Semua anggota sekolah telihat hidup rukun dan saling menghargai. Hal ini dilihat dari program $5 \mathrm{~S}$ yang diterapkan.

Salah satu tujuan pendidikan di SD Negeri 182/I Hutan Lindung Muara Bulian Jambi adalah dengan meningkatkan nilai religius peserta didik. Salah satunya adalah dengan meningkatkan moral dan akhlak. Menurut Mutohar (2016), strategi yang dapat dilakukan Guru PAI dalam meningkatkan nilai relegius di sekolah adalah: (a) memberikan contoh tauladan kepada siswa, (b) selalu membiasakan diri dengan hal-hal baik, (c) menjunjung tinggi kedisiplinan, (d) selalu memberikan motivasi, (e) menjaga psikologis anak, (f) memberi hukuman yang mendidik jika ada pelanggaran, (g) selalu berusaha menciptakan suasana yang religius sehinggaberpengaruh pada pertumbuhan anak. 
Vol. 12, No. 2 (2020)

Setelah dilakukan pengamatan dan wawancara, ternyata terlihat bahwa peran guru PAI sangat penting dalam menanamkan nilai religius. Dalam hal ini, bukti nyata yang menunjukkan bahwa guru PAI berperan penting dalam menanamkan nilai religius dapat dilihat seperti, kebiasaan memberikan senyum , salam, dan sopan santun, berdoa sebelum dan sesudah belajar, saling menghargai, dan menagadakan acara yasinan setiap hari jumat yang dilakukan rutin setiap hari sesuai dengan program dari sekolah. Pembiasaan seperti itu sangat penting dilakukan dalam rangka melestarikan dan meningkatkan nilai religius siswa yang dapat dilakukan oleh Guru PAI. Menurut Munif (2016), adanya pembiasaan akan kegiatan religius disekolah merupakan hal penting supaya pengembangan nilai religius terutama dalam menjadi budaya agama yang pokok di sekolah, karena kegiatan tersebut adalah hasil dari adanya proses latihan dan pembiasaan terus menerus sehingga akan menjadi budaya di sekolah.

Berdasarkan hasil paparan hasil wawancara pada guru PAI di SD Negeri 182/I. Hutan Lindung dapat peneliti simpulkan bahwa peran orang tua dalam mendukung gerakan literasi sekolah sangatlah besar. Hal ini juga dapat dilihat dari kondisi sekolah yang terlihat aman, damai dan tentram sesama siswa. Keadaan ini dikarenakan guru PAI selalu menekankan kepada siswa mengenai pentingnya toleransi dan harus sejalan juga dengan ibadah yang rutin dilakukan.

Dalam kondisi di atas bukan berarti guru PAI tidak memiliki kendala dalam melakukannya. Guru PAI tentu saja menghadapi kendala seperti siswa yang nakal ataupun susah diatur. Namun untuk mengatasi hal tersebut guru PAI selalu menyelesaikannya dengan orang tua siswa yang bersangkutan untuk menyelesaikan permasalahan yang ada serta cara-cara lain yang memungkinkan sebagai penyelesaian dari masalah tersebut. Menurut Ganjar Widodo (2017), selain berkomunikasi sengan orang tua siswa, hal lain yang dapat dilakukan untuk mengatasi permasalahan tersebut seperti memperbaiki komunikasi dengan siswa bersangkutan seperti memberikan arahan, pemberian motivasi, menunjukkan pilihan baik buruknya perilaku serta adanya pembiasaan dari guru kepada siswa untuk selalu melakukan hal-hal yang baik. Sehingga permasalahan tersebut bisa diatasi.

\section{SIMPULAN}

Dari hasil pengamatan yang telah dilakukan, didapatkan bahwa peran guru PAI sangat besar dalam menanamkan nilai religius di sekolah. Setelah melakukan penelitian, siswa SD Negeri 182/I Hutan Lindung telah memiliki nilai moral dan akhlak yang baik. Siswa terlihat aman, damai, dan hidup rukun. bimbingan belajar dan bimbingan perkembangan sikap atau tingkah laku. Dengan adanya peran guru PAI ini siswa mendapatkan banyak sekali bentuk perbaikan dan peningkatan terhadap nilai religious yang mereka miliki. Sehingga guru dapat terus bisa memberikan bimbingan yang dimaksudkan agar setiap peserta didik disadarkan 
Al-Ishlah: Jurnal Pendidikan - ISSN: 2087-949o (p); 2597-940X (e)

Vol. 12, No. 2 (2020)

mengenai kemampuan dan potensi dirinya yang sebenarnya dalam kapasitas belajar dan bersikap. Jangan sampai peserta didik menganggap rendah kemampuannya sendiri dalam potensinya untuk belajar dan bersikap atau bertingkah laku sesuai dengan ajaran Islam. Peneliti berharap dengan adanya jurnal ini dapat menambah wawasan bagi para pembaca dan peneliti menyarankan agar dalam menanamkan nilai religius bukan hanya tugas guru PAI melainkan tugas bersama guna melahirkan manusia yang berakhlak dan bermoral.

\section{DAFTAR PUSTAKA}

Abdul Mujib, A. M., \& Jusuf Mudzakkir, J. M. (2007). Ilmu pendidikan islam. Kencana Prenada Media Group.

Beny, A. (2016). Strategi guru Pendidikan Agama Islam (GPAI) dalam meningkatkan religiusitas siswa muslim di SMP Taman Harapan Malang (Doctoral dissertation, Universitas Islam Negeri Maulana Malik Ibrahim).

Damsar, D. (2011). Pengantar Sosiologi Pendidikan. Jakarta, Kencana.

Widodo, G. S., Hariyono, H., \& Hanurawan, F. (2017). Persepsi Guru tentang Kenakalan Siswa: Studi Kasus di Sekolah Dasar "Raja Agung”. Jurnal Pendidikan dan Pembelajaran (JPP), 23(2), 142-153.

Khoiriyah. (2012). Menggagas Sosiologi Pendidikan Islam. Yogyakarta: Teras.

Mufidah, M. (2019). Peran guru PAI dalam meningkatkan mutu Pendidikan Agama Islam di SMP Darul Ulum Agung Malang (Doctoral dissertation, Universitas Islam Negeri Maulana Malik Ibrahim).

Munif, M. (2016). Pengembangan Pendidikan Agama Islam Sebagai Budaya Sekolah. PEDAGOGIK: Jurnal Pendidikan, 3(2).

Mutohar, P. M. (2016). Pengembangan Budaya Religius (Religious Culture) di Madrasah: Strategi Membentuk Karakter Bangsa Peserta Didik. Didaktika Religia, 1(1).

Nangimah, N. (2018). Peran guru PAI dalam pendidikan karakter religius siswa SMA N 1 Semarang (Doctoral dissertation, UIN Walisongo Semarang).

Wiyani, Novan Ardy. (2013). Desain Pembelajaran Pendidikan: Tata Rancang Pembelajaran Menuju Pencapaian Kompetensi. Yogyakarta: Ar-Ruzz Media.

Wiyani, N. A. (2012). Pendidikan Karakter Berbasis Iman dan Taqwa. Teras. 
Al-Ishlah: Jurnal Pendidikan - ISSN: 2087-949o (p); 2597-940X (e)

Vol. 12, No. 2 (2020)

Rosidah, F. (2017). Implementasi nilai-nilai religius dan sosial dalam pembelajaran berbasis sentra dan area pada anak usia dini: studi multi kasus di kelompok bermain Muslimat Nahdhatul Ulama 73 Al Fitriyah Desa Peganden dan kelompok bermain Anggrek Desa Pongangan Kecamatan Manyar Kabupaten Gresik (Doctoral dissertation, Universitas Islam Negeri Sunan Ampel).

Sjarkawi, (2005).Pembentukan Kepribadian Anak. Jakarta: PT Bumi Aksara

Syahraini Tambak. (2014). Pendidikan Agama Islam Konsep Metode Pembelajaran PAI, 141-146.

Thontowi, A. (2012). Hakekat Religiusitas, (http://www. sumsel. kemenag.go.id), diakses 6 Januari 2018. 